\title{
ENSURING RIGHT TO FREEDOM OF SPEECH AND EXPRESSION ON CYBER SPACE AS AGAINST STATE INTERVENTION - INDIAN EXPERIENCE
}

\author{
ASSEGURANDO O DIREITO À LIBERDADE DE MANIFESTAÇÃO E EXPRESSÃO \\ NO ESPAÇO CIBERNÉTICO E TAMBÉM EM FACE DA INTERVENÇÃO ESTATAL \\ - A EXPERIENNCIA INDIANA
}

Nagarathna Annappa

Associate Professor of Law \& Chief Coordinator, Advanced Centre on Research, Development \& Training in Cyber Laws \& Forensics, National Law School of India University, Bengaluru, India.

\section{Resumo}

Embora a Internet tenha sido extremamente vantajosa para conectar pessoas e fornecer uma plataforma para a expressão de seus pontos de vista e opiniões, por outro lado, às vezes, leva ao abuso desta plataforma por parte de algumas regulamentações legais necessárias. A liberdade de manifestação e expressão, sendo um direito fundamental, é juridicamente exigível em face do Estado e suas agências, mas a mesma pode ser legalmente restringida sob certos "motivos razoáveis". Este artigo tem como objetivo analisar o arcabouço jurídico existente a esse respeito, com o objetivo de identificar as disposições legais que, por um lado, protegem a liberdade de manifestação e expressão no ciberespaço e, por outro, restringem essa liberdade. Embora o artigo faça uma breve avaliação do aspecto jurídico em questão, do ponto de vista internacional, ele se concentra amplamente na estrutura do direito indiano a esse respeito.

Palavras-chave: Liberdade de Manifestação e Expressão, Ciberespaço, Restrições Razoáveis, Internet.

\begin{abstract}
While Internet has been extremely advantageous in connecting people and providing a platform for expression of one's views and opinions, on the other hand it has even at times lead to abuse of this platform by some necessitating legal regulation. Freedom of speech and expression being a fundamental right is legally enforceable even against the State and its agencies but the same can be legally
\end{abstract}


restricted under certain 'reasonable grounds'. This paper aims to analyse the existing law framework in this regard, with the object of identifying legal provisions which on one hand protects freedom of speech and expression on cyber space and on the other hand, the legal restrictions imposed for such freedom. Though the paper makes a brief assessment of the concerned legal aspect from international perspective in brief, it focuses largely on Indian law framework in this regard.

Key words: Freedom of Speech \& Expression, Cyber Space, Reasonable Restrictions, Internet.

\section{INTRODUCTION}

Right to freedom of speech and expression is the one of the most cherished right of an individual. International and national legal instruments recognise it as a human right. In India, like in many other democratic countries, right to freedom of speech and expression is guaranteed as a fundamental right to its citizens.

With the advent of cyber technology, a parallel platform for communication also began thereby connecting people not just for electronic commercial and governance related transactions but also for communicating with each other. Today's most of the personal as well as official communication happens through the usage of Internet technology.

Internet technology comes with its own unique characteristic features hence usage of it for communication purpose require a review from legal perspective, at time through a regulatory mechanism. However such regulation should not lead to unfair and unjust interference with the freedom of speech and expression on cyber space. At the same time, illegal content should also not be allowed to be hosted on internet in the name of free speech. Hence State's intervention into the right is legally provided as well as recognised in form of provisions form Indian Cyber laws and criminal laws and judicial precedents.

On this specific aspect, few researchers in India have explored the dimension of the internet and freedom of speech. A comparative analysis of the constitutional issues of freedom of speech in the USA and India highlighting the obscenity laws were made in which an analysis was made to check if certain legal tests could be applied to determine freedom of expression on internet (Damania, 
Farad, 2002) ${ }^{1}$. But freely made speech can also constitute hate speech which has the potential to create inter cultural or cross-cultural conflict (Sungsuran, Kitsuron, 2013) $)^{2}$. The imbalances between age old legal procedure adopted by Indian law enforcement agencies on one hand and the technological advancements happening on the other hand, have raised concerns pertaining to freedom of speech and as well as privacy. (Inder, Sharma \& Alam, Afshar. M, 2016) ${ }^{3}$. In addition, the complexities of use and misuse of freedom of speech and expression on cyberspace in a growing and developing digital Indian scenario has increased (Bakshi, Anil Kumar, 2018). ${ }^{4}$

There is a normal perception that freedom of speech and expression is controlled completely by the State, even on cyber space. But internet intermediaries as industries are also involved in internet regulation especially content regulation, thereby raising concerns related to freedom of speech and expression of internet users. Intermediaries at times even go beyond the tenets of the municipal law while exercising this power, thereby necessitating legal response. Law must apart from determining the extent of this regulatory power of internet, ensure procedural fairness which currently is lacking.

Indian laws with constitutional legal provisions though can regulate abuse of powers of State on this aspect, yet fails to impose similar restrictions on internet intermediaries. Often social media accounts are blocked or suspended by concerned media platform without adhering to any fair procedure thus raising questions about freedom of speech and expression. It is important to note that the concerned States even if have laws to resolve this, its effectiveness depends on its enforcement abilities. Enforcement abilities further get affecting due to jurisdictional challenges. This paper focuses on assessing the manner in which India has addressed the concerns of internet users' freedom of speech and expression getting affected today due to cyber technology. Exercise of this right over cyber space often comes under serious attack due to censoring and other regulatory mechanisms adopted by State.

1Damania, Farad: The Internet: Equalizer of freedom of speech? A discussion on freedom of Speech on the internet in the United States and India, Indian International \& Comp. Review Vol 12 No.2 (2002).

2Sangsuran, Kitsuron: Balancing freedom of Speech on the Internet under International law, 39, NCJ International Law and Com.Reg, 701 (2013).

${ }^{3}$ Sharma, Indu \& Alam, Afshar. M: privacy \& freedom issues in Cyberspace with reference to Cyber law, International Journal of Computer Applications (0975-8887) Vol.145 No.3 July, 2016.

${ }^{4}$ Bakshi, Anil Kumar : the complexities of freedom of speech and expression in cyber space in Digital India : International Journal of Emerging Technology and Innovative Research, Vol. 5, Issue 8 pp. 444 -446 (Aug, 2018) 
For a better exercise of this fundamental right on cyber space, laws must clearly specify grounds on which such right can be restricted apart from laying down the extent of such restrictions with procedural rules also being clearly indicated.

\title{
INTERNATIONAL LEGAL INSTRUMENTS:
}

\begin{abstract}
"We reaffirm, as an essential foundation of the Information Society, and as outlined in Article 19 of the Universal Declaration of Human Rights, that everyone has the right to freedom of opinion and expression; that this right includes freedom to hold opinions without interference and to seek, receive and impart information and ideas through any media and regardless of frontiers."World Summit on the Information Society. ${ }^{5}$
\end{abstract}

While international legal instrument including Universal Declaration of Human Rights under Article 19, declares right to freedom of speech as an important human right, thereby insisting member States to ensure its citizens right to freedom of speech, it is important to ensure that the same is also legally recognised in today's context of cyber space.

The United Nation's General Assembly, Human Rights Council Twentieth Session ${ }^{6}$ passed the resolution, on Promotion and protection of all human rights, civil, political, economic, social and cultural rights, including the right to development', in which it noted that the exercise of human rights, in particular the right to freedom of expression, on the Internet is an issue of increasing interest and importance as the rapid pace of technological development enables individuals all over the world to use new information and communications technologies. It hence affirmedthat the same rights that people have offline must also be protected online, in particular freedom of expression, which is applicable regardless of frontiers and through any media of one's choice, in accordance with Articles 19 of the Universal Declaration of Human Rights and the International Covenant on Civil and Political

5 Document WSIS-03/GENEVA/DOC/4-E, $12^{\text {th }}$ December 2003 , available at http://www.itu.int/net/wsis/docs/geneva/official/dop.html. last visited on $20^{\text {th }}$ November 2020.

$620 / L 13 \ldots$ The Promotion, Protection and Enjoyment of Human Rights on the Internet, A/HRC/20/L.13 (June 29, 2012), 
Rights. ${ }^{7}$ The UN's Human Rights Council on July 5, 2012 unanimously adopted the first resolution to protect the free speech of individuals on the Internet. ${ }^{8}$

UNESCO also recognizes the importance of ensuring protection to right to freedom of speech and expression on cyber space. It holds that "the principle of freedom of expression and human rights must apply not only to traditional media but also to the Internet and all types of emerging media platforms, which will contribute to development, democracy and dialogue." 9 It is hence clear that today internationally the need to extend protection to freedom of speech and expression on cyber space is felt.

"Governments have a responsibility to ensure compliance with national and international law, but they must act now to ensure that the ability of internet platforms to provide space for freedom of expression is not undermined." David Kaye. ${ }^{10}$

\section{INDAIN LAW FRAMEWORK:}

In Indian, Article 19(1) (a) of the Constitution guarantees freedom of speech and expression as per following:

"All citizens shall have the right (a) to freedom of speech and expression".

But the said right [to freedom of speech and expression guaranteed under Article 19(1)(A) is subject to reasonable restrictions placed thereon by an existing law or a law made after the commencement of the Constitution in the interests of or in relation to the several matters set out therein. ${ }^{11}$ According to Article 19(2):

"Nothing in sub clause (a) of clause (1) shall affect the operation of any existing law, or prevent the State from making any law, in so far as such law imposes reasonable restrictions on the exercise of the right conferred by the said sub clause in the interests of - the

\footnotetext{
7 See: Ibid and https://www.loc.gov/law/foreign-news/article/u-n-human-rights-council-first-resolutionon-internet-free-speech/,last visited on $20^{\text {th }}$ November 2020.

${ }^{8} \mathrm{https} / / / \mathrm{www}$. loc.gov/law/foreign-news/article/u-n-human-rights-council-first-resolution-on-internetfree-speech/, last visited on $20^{\text {th }}$ November 2020.

${ }^{9} \mathrm{https}: / /$ en.unesco.org/themes/freedom-expression-internet, last visited on $10^{\text {th }}$ November 2020.

10 David, Kave, UN Special Rapporteur on the promotion and protection of the right to freedom of opinion and expression. See: https://www.ohchr.org/EN/NewsEvents/Pages/DisplayNews.aspx?NewsID=23218\&LangID=E, last visited on $11^{\text {th }}$ November 2020

${ }^{11}$ Supreme Court of India, in R. Rajagopal v. State of Tamil Nadu, 1995 AIR 264, 1994 SCC (6) 632.
} 
sovereignty and integrity of India, the security of the State, friendly relations with foreign States, public order, decency or morality or in relation to contempt of court, defamation or incitement to an offence"

It is hence important to ensure that one's freedom of speech and expression does not cross the reasonable restrictions as indicated above, failure of which legalises State's intervention into such right. The fundamental freedom under Article 19 [1] (a) can be reasonably restricted only for the purposes mentioned in Article 19 [2] and the restriction must be justified on the anvil of necessity and not the quicksand of convenience or expediency. ${ }^{12}$

\section{INDIAN PENAL CODE:}

There are various provisions of law through which free speech on cyber space can be curtailed in India. Indian Penal Code of 1860 being the Indian Substantive Criminal Law have provisions through which anything said or expressed, if amounts to illegal content thereby resulting in crimes indicated under respective legal provisions, can be made subject to criminal liability. Online posts which provokes disturbance to law and order or which leads to communal violence or any other crimes are broadly dealt with under Indian Penal code. Some of the most important provisions are as under:

(i) Section 124A: Sedition is made punishable under Section 124A of the Code, according to which any act including an online content which is in form of written or spoken words [thereby including along with written content, an audio or video content too], signs, visible representation or otherwise, which brings or attempts to bring in hatred or contempt or which excites or attempts to disaffection towards the Government is made punishable. Statutory explanation expands the scope of the provision by defining the term "disaffection" as that which includes disloyalty and all feelings of enmity. However, the provision does not include comments which expresses disapprobation of the measures of the Government with a view to obtain their alteration by lawful means, without exciting or attempting to excite hatred, contempt or disaffection. Further any comments that expresses disapprobation of the administrative or other action of the Government without

\footnotetext{
12 The Secretary, Ministry Of Information \& Broadcasting V. Cricket Association of Bengal \& Another, 1995 AIR 1236, 1995 SCC (2) 161
} 
exciting or attempting to excite hatred, contempt or disaffection also do not come under the offence of Sedition.

(ii) Section 117: Any online content leading to 'abetment of commission of an offence by the public generally or by any number or class of persons exceeding ten" is made punishable under Section 117 of the Penal Code.

(iii) Under Section 153, any act including an online comment or post which is made malignantly, or wantonly, thereby being illegal and giving provocation to the commission of the offence of rioting is made punishable with criminal liability.

(iv) Under Section 153A, promoting enmity between different groups on grounds of religion, race, place of birth, residence, language, etc., and doing acts prejudicial to maintenance of harmony is made punishable. This provision is also wide enough to include online posts leading to promotion of enmity between different groups. According to this section, a person is liable if he with his written or spoken words or by visible representations or otherwise, promotes or attempts to promote, on grounds of religion, race, place of birth, residence, language, caste or community or any other ground whatsoever, disharmony or feelings of enmity, hatred or ill-will between different religious, racial, language or regional groups or castes or communities. Further a person can also be held liable if he commits any act which is prejudicial to the maintenance of harmony between different religious, racial, language or regional groups or castes or communities, and which disturbs or is likely to disturb the public tranquillity.

(v) Section 153B, criminalises Imputations and assertions that are prejudicial to national-integration. According to this section, if a person

- by spoken or written words or by signs or visible representations or otherwise makes or publishes any imputation that any class of persons cannot, by reason of their being members of any religious, racial, language or regional group or caste or community, bear true faith and allegiance to the Constitution of India as by law established or uphold the sovereignty and integrity of India, or

- if he asserts, counsels, advises, propagates or publishes that any class of persons shall, by reason of their being members of any religious, racial, language or regional group or caste or community, be denied or deprived of their rights as citizens of India, or

- if he makes or publishes any assertion, counsel, plea or appeal concerning the obligation of any class of persons, by reason of their being members 
of any religious, racial, language or regional group or caste or community, and such assertion, counsel, plea or appeal causes or is likely to cause disharmony or feelings of enmity or hatred or ill-will between such members and other persons,

He is made punishable under this provision.

(vi) Section 295A imposes criminal liability upon a person who with deliberate and malicious intention of outraging the religious feelings of any class of citizens of India, by written or spoken words, or by signs or visible representations or otherwise, insults or attempts to insult the religion or the religious beliefs of that class.

(vii) According to Section 504 - it is a crime to "intentionally insult, and thereby giving provocation to any person, intending or knowing it to be likely that such provocation will cause him to break the public peace, or to commit any other offence." Hence an online content which leads to above offence can also be regulated under this provision.

(viii) According to Section 505, a person is punishable if he makes or publishes or circulates any statement, rumour or report:

- with an intention to cause, or which is likely to cause, any officer, soldier, [sailor or airman in the Army, Navy or Air Force of India to mutiny or otherwise disregard or fail in his duty as such; or

- with an intention to cause, or which is likely to cause, fear or alarm to the public, or to any section of the public whereby any person may be induced to commit an offence against the State or against the public tranquillity; or

- with an intention to incite or which is likely to incite, any class or community of persons to commit any offence against any other class or community

- Further, it also criminalises Statements creating or promoting enmity, hatred or ill-will between classes. Hence if a person makes, publishes or circulates any statement or report containing rumour or alarming news with intent to create or promote, or which is likely to create or promote, on grounds of religion, race, place of birth, residence, language, caste or community or any other ground whatsoever, feelings of enmity, hatred or ill-will between different religious, racial, language or regional groups or castes or communities, he is made punishable.

- $\quad$ it is interesting to note that the section exempts the punishment in case where a person makes, publishes or circulates any such statement, rumour or report, 
having reasonable grounds to believe that such statement, rumour or report is true and makes, publishes or circulates it in good faith and without any such intent as aforesaid.

Additionally Indian Criminal laws also regulates online content that is defamatory under Section 500, IPC;

\begin{abstract}
IPC under Section 354(1) (iv) for "making sexually coloured remarks" thereby committing the offence of sexual harassment. IPC under Section 506 - for posting any material which results in 'criminal intimidation' including that which 'leads to causing of threat to cause death or grievous hurt, or to cause the destruction of any property by fire, or to cause an offence punishable with death or imprisonment for life, or with imprisonment for a term which may extend to seven years, or to impute, unchastity to a woman."
\end{abstract}

\title{
THE UNLAWFUL ACTIVITIES (PREVENTION) ACT, 1967
}

The Act under Section 2 (0) defines the term "unlawful activity" as "in relation to an individual or association, means any action taken by such individual or association (whether by committing an act or by words, either spoken or written, or by signs or by visible representation or otherwise - (i) which is intended, or supports any claim, to bring about, on any ground whatsoever, the cession of a part of the territory of India or the secession of a part of the territory of India from the Union, or which incites any individual or group of individuals to bring about such cession or secession; or (ii) which disclaims, questions, disrupts or is intended to disrupt the sovereignty and territorial integrity of India; or (iii) which causes or is intended to cause disaffection against India." This enactment hence wide enough to cover usage of words, signs and visible representation even on cyber space. According to Section 13 (1) "(a) Whoever takes part in or commits, or (b) advocates, abets, advises or incites the commission of, any unlawful activity, shall be punishable with imprisonment for a term which may extend to seven years and shall also be liable to fine." Further, according to Section 18, "Whoever conspires or attempts to commit, or advocates, abets, advises or incites, directly or knowingly facilitates the commission of, a terrorist act or any act preparatory to the commission of a terrorist act, shall be punishable with imprisonment for a term which shall not be less than five years but which may extend to imprisonment for life, and shall also be liable to fine." The 
words used in these provisions are wide enough to over usage of online platform for commission of offences of unlawful activities and conspiracy and attempt to commit terrorist act. It is however necessary to give a wider legal interpretation to such effect, keeping in mind the object of the Act.

\section{INDIAN INFORMATION TECHNOLOGY ACT, 2000:}

Indian Information Technology Act of 2000 under Section 66A had attempted to regulation online communications by stating as follows:

"Punishment for sending offensive messages through communication service, etc.: Any person who sends, by means of a computer resource or a communication device,-

(a) any information that is grossly offensive or has menacing character; or

(b) any information which he knows to be false, but for the purpose of causing annoyance, inconvenience, danger, obstruction, insult, injury, criminal intimidation, enmity, hatred or ill will, persistently by making use of such computer resource or a communication device; or

(c) any electronic mail or electronic mail message for the purpose of causing annoyance or inconvenience or to deceive or to mislead the addressee or recipient about the origin of such messages,

shall be punishable with imprisonment for a term which may extend to three years and with fine."

The Statutory explanation to provision further provided as follows:

"For the purpose of this section, terms "electronic mail" and "electronic mail message" means a message or information created or transmitted or received on a computer, computer system, computer resource or communication device including attachments in text, image, audio, video and any other electronic record, which may be transmitted with the message."

This provision imposed criminal liability upon one for sending any content that had content which is 'grossly offensive' or had 'menacing character' or any false information sent to cause 'annoyance, inconvenience, danger, obstruction, insult, injury, criminal intimidation, enmity, hatred or ill will' to a person persistently or which was sent to cause 'annoyance or inconvenience or to deceive or to mislead the addressee or recipient about the origin of such messages.' The statute however did 
not define terms such as - 'annoyance', 'menacing character' etc. thereby adding vagueness to the provision. The scope of the provision was too wide to include many forms and incidences of sharing of one's views, opinions and thoughts.

It is important to note that this crime was also declared as "cognizable" offence, meaning thereby that the police had obligation to investigate this case and their power of investigation also included power to arrest the wrong doer. The usage of this provision had led to couple of arrest incidences in India raising questions of legality of the provision and possibility of its abuse by State. ${ }^{13}$ :

A Public Interest Litigation filed by a law student before Supreme Court of India lead to judicial scrutiny of the provision in the case of Shreya Singhal v. Union of India. ${ }^{14}$ The court held section $66 \mathrm{~A}$ as being "vague and overbroad, and, therefore, unconstitutional under Article 19(1) (a) and not saved by Article 19(2)."

However it is interesting to note that in the two Mumbai girl's arrest incident the Mumbai police had also invoked provisions of "Sections 295 (A) deliberate and malicious acts, intended to outrage religious feelings or any class by insulting its religion or religious beliefs), 505(2) (statements creating or promoting enmity, hatred or ill-will between classes" 15 along with Section 66A of the Information Technology Act. While the Supreme Court verdict has only lead to repeal of Section 66A of the IT Act, on the other hand other provisions regulating free speech including from IPC continues to apply even today. Hence, even now, provisions from other laws, including Indian Penal code can be invoked to regulate free speech including on cyber space.

Information Technology Act also regulates publication of following contents on internet platform:

Porn and obscene contents under Section 67 and 67A and

Child porn material under Section 67B

13 See for information on more such cases - https://indianexpress.com/article/india/indiaothers/section-66-a-instances-of-alleged-abuse-on-social-media-2324927/, last visited on $19^{\text {th }}$ November 2020.

${ }^{14}$ AIR 2015 SC 1523.

${ }^{15} \mathrm{https}: / /$ www.firstpost.com/mumbai/thackeray-fb-arrest-police-file-closure-report-all-charges-on-girlsdropped-562156.html, last visited on $19^{\text {th }}$ November 2020. 


\section{EMERGING ISSUES OF “ACCESS TO INTERNET.”}

In the context of internet blocking orders issued by Union of India in the State of Jammu and Kashmir, the Supreme Court of India in the case of Anuradha Bhasin v. Union of India while attempting to "provide a meaningful answer so that every citizen has adequate security and sufficient liberty", rightfully observed that, "the pendulum of preference should not swing in either extreme direction so that one preference compromises the other. It is not our forte to answer whether it is better to be free than secure or be secure rather than free. However, we are here only to ensure that citizens are provided all the rights and liberty to the highest extent in a given situation while ensuring security at the same time."

The petitioner's argument in this case included that "Curtailment of the internet, is a restriction on the right to free speech, should be tested on the basis of reasonableness and proportionality." The State in this case had also invoked its power under Section 144 of the Criminal Procedure Code. With regard to this, the petitioners contended that "such an order is made to deal with a 'law and order' situation, but the orders do not indicate any existing law and order issue, or apprehension thereof." The Supreme Court most importantly held as follows:

"We declare that the freedom of speech and expression and the freedom to practice any profession or carry on any trade, business or occupation over the medium of internet enjoys constitutional protection under Article 19(1) (a) and Article 19(1) (g)."

\section{OBLIGATIONS OF INTERNET INTERMEDIARIES TO ASSIST STATE IN INTERVENTION ACTIVITIES}

While State's power of intervention into the right of an individual to freedom of speech and expression is justified on reasonable grounds under Article 19(2), at times in order to make such intervention on cyber space, it is important to ensure that internet intermediaries cooperate with the State and its agencies. An Intermediary is subjected to following legal obligations by the Information Technology Act, 2000: 
to assist state in internet interception or monitoring or decryption of any information through any computer resource under Section 69

to assist State in blocking from public access of any information through any computer resource under Section 69A and

- $\quad$ to assist State in monitoring and collecting traffic data or information through any computer resource for Cyber Security under Section 69B.

Additionally Section 79 of the Information Technology Act and the Information Technology (Intermediaries guidelines) 2011 obligates the Internet Intermediaries to comply with due diligence requirement. 'Due diligence' compliance requires them to inform "the users of computer resource not to host, display, upload, modify, publish, transmit, update or share any information that:

a) belongs to another person and to which the user does not have any right to;

b) is grossly harmful, harassing, blasphemous defamatory, obscene, pornographic, paedophilic, libellous, invasive of another's privacy, hateful, or racially, ethnically objectionable, disparaging, relating or encouraging money laundering or gambling, or otherwise unlawful in any manner whatever;

c) harm minors in any way;

d) infringes any patent, trademark, copyright or other proprietary rights;

e) violates any law for the time being in force; e) deceives or misleads the addressee about the origin of such messages or communicates any information which is grossly offensive or menacing in nature;

f) impersonate another person"16

An intermediary can also remove access to any information, data or communication link by an intermediary after such information, data or communication link comes to the actual knowledge of a person authorised by the intermediary pursuant to any order or direction as per the provisions of the Act. ${ }^{17}$

The Supreme Court clarified that the "Section 79(3)(b) has to be read down to mean that the intermediary upon receiving actual knowledge that a court order has been passed asking it to expeditiously remove or disable access to certain material must then fail to expeditiously remove or disable access to that material. This is for

\footnotetext{
${ }^{16}$ Rule 2

17 Rule 3(b)
} 
the reason that otherwise it would be very difficult for intermediaries like Google, Facebook etc. to act when millions of requests are made and the intermediary is then to judge as to which of such requests are legitimate and which are not. We have been informed that in other countries worldwide this view has gained acceptance, Argentina being in the forefront. Also, the Court order and/or the notification by the appropriate Government or its agency must strictly conform to the subject matters laid down in Article 19(2). Unlawful acts beyond what is laid down in Article 19(2) obviously cannot form any part of Section 79. With these two caveats, we refrain from striking down Section 79(3) (b)."18 The Court further said that "Section 79 is valid subject to Section 79(3)(b) being read down to mean that an intermediary upon receiving actual knowledge from a court order or on being notified by the appropriate government or its agency that unlawful acts relatable to Article 19(2) are going to be committed then fails to expeditiously remove or disable access to such material. Similarly, the Information Technology "Intermediary Guidelines" Rules, 2011 are valid subject to Rule 3 sub-rule (4) being read down in the same manner as indicated in the judgment."

Thus in this decision, the Apex Court of the Country has tried to balance an individual's right to freedom of speech with the need to regulate such right in reasonable circumstances by empowering the State. The law further obligates the Internet intermediaries on one hand have to also ensure protection of its user's right to freedom of speech and expression apart from rendering assistance to State during its intervention done on the grounds of 'reasonable restrictions'. India hence adopts an approach of balancing the two vital concerns of individual as well as State.

\section{INTERNET INTERMEDIARIES RESTRICTING INTERNET USAGE - A CONCERN UNADDRESSED BY STATE AND ITS LAWS}

- Amul's Twitter account was briefly blocked on June 4 and restored the next day. ${ }^{19}$

- $\quad$ Twitter on Friday said Union Home Minister Amit Shah's account was temporarily locked due to an "inadvertent error" and the decision was reversed. 20

\footnotetext{
18 Shreya Singhal v. Union of India, AIR 2015 SC 1523.

19https://scroll.in/latest/964035/amuls-twitter-account-blocked-briefly-social-media-firm-cites-securityprocesses, last visited on $19^{\text {th }}$ November 2020.
} 
As mentioned before, an internet intermediary according to intermediary guidelines, Rule 3(b) can block or remove access to any information, data or communication link provided by them if such content is against the laws of India. Additionally social media platforms also have laid down their own 'standards' and 'process' to impose these restrictions. Many times such restrictions are important especially to exercise timely actions against blatantly illegal contents such as child porn material or material which can lead to violence, etc. But exercising this power without checks and balances raises concerns of freedom of speech of internet users, hence the need to have a legal framework. India currently lacks such framework. The standards considered by such internet intermediaries are also not often transparent thereby raising questions of legality from the context of concerned State's municipal laws. State hence must legally address this aspect by revising laws to tackle this concern. While industries are expected to be responsible on what they let to be hosted or published on their platform in order to claim 'safe harbour' protection $^{21}$, they are also expected not to unnecessarily interfere with the right of freedom of speech of their platform's users.

Though this is not an interference of internet user's right by State or its agencies, yet failure on the part of State to extend its protection to its citizen's right to freedom of speech and expression as against industry's unregulated interference calls for State's action and intervention. Citizen's fundamental right protection even against non-state entities intervention is expected to be taken care of by State. Existing legal provisions such as Section 79 and internet intermediaries may also not be helpful enough since its effectiveness gets often affected due to jurisdiction related concerns, as often social media platforms in dispute may not be Indian based. Thus a further need to empower State on this aspect so that it is able to protect its citizen's right to freedom of speech on cyber space more effectively. This also requires better enforcement mechanism.

\footnotetext{
20 The Hindu, November 13, 2020, available at https://www.thehindu.com/news/national/twitter-saysamit-shahs-account-was-temporarily-locked-due-to-inadvertent-error/article33090690.ece, last visited on $20^{\text {th }}$ November 2020.

${ }^{21}$ Protection conferred upon internet intermediaries against legal liability for third parties' illegal acts, provided upon fulfilment of conditions of 'absence of knowledge' and compliance to 'due diligence'. For Example: Section 79, Information Technology Act, 2000.
} 


\section{CONCLUSION}

Internet today has provided an easier and most accessible platform to all for communication. Platforms such as social media is often used to share views and expressions of varied nature, including political, religious, etc. however if such communication leads to commission of any offence it is necessary to legally regulate the same. But it important to ensure that such regulation is legal, fair and just. Since it's also about ensuring equal protection of freedom of speech and expression on cyber space, like an offline platform, it is more important to understand the scope of such legal regulation.

Illegal contents must be regulated but without compromising on the fundamental rights of internet users. Many times, social media accounts are blocked or suspended by intermediaries as well as States either without complying with any legal process or by following a process which is opaque, thereby denying the internet user's right to freedom of speech and expression. It is important for laws to consider all these conflicting concerns so as to balance the interests of all stakeholders. While Constitutional legal provisions are clear on this aspect, the current intermediary laws lacks certainty. India must hence reframe its rules on this aspect addressing the above mentioned concerns so that internet user's right to freedom of speech and expression is better enforced on cyber space

Recebido em 23/11/2020

Aprovado em 26/04/2021

Received in 23/11/2020

Approved in 26/04/2020 